\title{
Tactful Acquisitions\& merger of The Walt Disney Company improved its performance, showed by financial \& industry analysis
}

\author{
Madiha Latif \\ Lecturer, The Islamia University of Bahawalpur Pakistan \\ Jawwad Hassan Jaskani (Corresponding Author) \\ Student, The Islamia University of Bahawalpur Pakistan \\ Email:jjaskanis@gmail.com
}

Name: Tehreem Ilyas

Student, The Islamia University of Bahawalpur Pakistan

Irum Saeed

Student, The Islamia University of Bahawalpur Pakistan

Kaynaat Shah

Student, The Islamia University of Bahawalpur Pakistan

Nida Azhar

Student, The Islamia University of Bahawalpur Pakistan

Accepted: August 04, 2014

DOI: 10.5296/ijafr.v4i1.6082ＵRL: http://dx.doi.org/10.5296/ ijafr.v4i1.6082

\begin{abstract}
Case overview -This case contains detailed information about Walt Disney Co. that gives knowledge about its business environment, acquisitions \& merger, market position \&
\end{abstract}




\section{MInstitute Macrothink $_{\text {Int }}$}

International Journal of Accounting and Financial Reporting ISSN 2162-3082 2014, Vol. 4, No. 1

company performance. This study traces the reporting of the financial performance in Walt Disney as compared to the industry. Walt Disney was established in 1923 with a small sketch but now it is a giant as well as the market leader. Walt Disney is a market leader for a long time and is operating efficiently in the market. This case study illustrates its financial performance by comparing its financial data from 1999 to 2013. The company is growing year over year through acquisitions and mergers with the other firms. The company's performance has been analyzed through various analysis and financial techniques to elaborate the actual financial condition of the company. The experiences gained from the current study will serve the businesses in entertainment industry through providing help full insights for the tactful strategies \& elimination of financial risks. The unique analysis of the market helps to manage business environment. Also play a significant role in the development of a theoretical base for further research studies in the field of finance as well as for learning purposes.

Expected learning outcomes - The objective of this case study is to demonstrate the critical success factors particularly in financial terms which provides a solid base for a business group to sustain its competitive position $\&$ market leader in the industry. The readers are expected to get numerous benefits from this case study. Like an understanding of calculation $\&$ interpretation of basis financial ratios \& its implications for investors, creditors \& financial managers which strengthen their decision making, and it also help researchers who keen about this industry, significance of various financial analyses for a business organization.

Keywords: Walt Disney, Entertainment Diversified Industry, Financial Ratio analysis

\section{Introduction}

The Walt Disney Company was found on October 16, 1923 began with Walt \& Roy Disney brothers as animation studio. For more than nine decades, Walt Disney is the world's leader \& preeminent in the field of high quality family entertainment, with its multiplicity of diversified businesses and distinctive brands. The Company has headquartered in Burbank, California, U.S.Mickey Mouse is the first cartoon character appeared in the animated movie named "Steamboat Willie".WaltDisney name has symbolized innovation, creativity, true, decency, optimism and quality. The Walt Disney Company is known for its persuasive entertainment proficiencies. Sincemodernizing the way people associate with sports, to creating new realities in interactive experiences, it is enthusiastic to submerging guests, audiences and consumers in never-before-seen ways (Thewaltdisneycompany.com). Many engineers, entertainers and business innovators work together to createpositively engaging stories, content and experiences that are supported by global brands also locally and culturally relevant.

The customer side of Disney also rose from modest commencements. The major strength of Walt Disney is its incredible family of employees and cast participantsall over the world, each of whom bring unique passion, perspective and thoughts to work every day. It provides best quality entertainment for every member of the family and around the world. The company's most important financial objectives are to maximize cash flow\& earnings, and to allocate capital toward growth initiatives that will drive long-term shareholder value. In March 2011, WaltDisney was named \#1 in entertainment on world's most admired companies by Fortune. 


\section{Macrothink}

International Journal of Accounting and Financial Reporting ISSN 2162-3082

Disney doing creative efforts, that made it a more expensive \& innovational company than ever.

\section{Walt Disney Segment Analysis}

Walt Disney together with its subsidiaries \&affiliates is the world's largest \& leading media conglomerate in the world in terms of revenue. It is a diversified worldwide entertainment company, together with its subsidiaries. Disney operates in five business segments, first is Media Networks, second is Parks and Resorts, and third is Studio Entertainment; forth one is Consumer Products and last one is Interactive. Media Networks is first segment that includes international and national cable television networks, an inland broadcast television network, television production operations, national and international television distribution, national television stations, national broadcast radio networks and stations, and publishing and digital operations. Media network segment accounted for $45.19 \%$ of Disney's revenue in 2013. The Parks and Resorts segment functions the Walt Disney World Resort in Florida, the Disneyland Resort in California, Aulani, and a Disney Resort \& Spa in Hawaii, the Disney Vacation Club, the Disney Cruise Line and Adventures by Disney. Park \& resort segment accounted for 31.28\% of Disney's revenue in 2013. Third segment is Studio Entertainment which produces and acquires live-action and animated motion pictures, musical recordings direct-to-video content, and live stage plays. Studio segment accounted for $13.28 \%$ of Disney's revenue in 2013. The Consumer Products segment involves others publishers, licensees and retailers throughout the world who project, improve, broadcast, stimulate and sell a wide-ranging variability of products based on surviving and new characters and other Company intellectual property through its Merchandise Licensing, Publishing and Retail businesses. Consumer products segment accounted for $7.89 \%$ of Disney's revenue in 2013 . The Interactive segment constructs and carries branded entertainment and lifestyle content across interactive media platforms. The major operating businesses of Interactive are Interactive Games which produces multi-platform games for worldwide distribution, which develops branded online services. Interactive segment accounted for $2.36 \%$ of Disney's revenue in 2013.(Annual Reports Walt Disney, 2013)

Condensed Statement of Financial Performance 2009 to 2013

\begin{tabular}{|l|l|l|l|l|l|}
\hline Particulars & $\mathbf{2 0 0 9}$ & $\mathbf{2 0 1 0}$ & $\mathbf{2 0 1 1}$ & $\mathbf{2 0 1 2}$ & $\mathbf{2 0 1 3}$ \\
\hline Revenues & 36,149 & 38,063 & 40,893 & 42,278 & 45,041 \\
\hline $\begin{array}{l}\text { Net } \\
\text { Earnings }\end{array}$ & 3,307 & 3,963 & 4,807 & 5,682 & 6,136 \\
\hline Dividends & 0.35 & 0.40 & 0.60 & 0.75 & 0.86 \\
\hline $\begin{array}{l}\text { Stock } \\
\text { Prices }\end{array}$ & 30.52 & 35.89 & 36.48 & 49.18 & 76.40 \\
\hline
\end{tabular}


(Note: Above mentioned figures are in millions Dollar)

Total Disney's profitability\& revenues has wide-ranging over the last five years. Revenue peaked at over \$ 45B in 2013 and dropped to less than \$36 in 2009. Disney's financial performance shows that revenues are increasing every year. Disney's stock price has varied from a high of over $\$ 76.40$ in 2013 to a low price of less than $\$ 30.52$ December in 2009. Walt Disney (DIS) has endorsed a profit for every offer of $\$ 0.86-$ up $\$ 0.11$ from 2012 . The net pay for shareholders was recorded at $\$ 5.7$ billion, a sensational expansion of $18 \%$ from 2011 . In like manner, incomes were recorded at $\$ 42.3$ billion, 3\% higher than 2011. At the heart of Walt Disney's remarkable achievement has been its obtaining of real media brands including the accompanying organizations: Lucas film, Marvel, Pixar, ABC and ESPN. This permits the organization to keep on operating at the forefront, giving top-level stimulation choices to individuals everywhere throughout the world. Disney has made a propensity of picking victors, supporting them and appreciating solid benefits from these organizations.

\section{Industry Analysis}

Walt Disney lies under the "Entertainment - Diversified" industry category as a service division. The Walt Disney Company has a prominent history in the diversion business, extending in excess of 75 years. Disney is a settled aggregate firm with a strong mastery inside the amusement park and diversion industry. Liberty Media Interactive, Time Warner Inc., Liberty Capital Group, News Corp. and Liberty Starz Group are the Walt Disney Company's primary rivals inside entertainment industry. Despite the fact that the Walt Disney Company is a business sector pioneer, these different contenders can posture conclusive troubles on the grounds that they are all expanded combinations with robust vicinity inside the worldwide business sector.

\section{Industry: Entertainment - Diversified}

The Entertainment industry involves those businesses that produce and distribute motion pictures, audio recordings and music. There are over 200 companies in this industry \& there are key payers that control the majority of the market. Key players are The Walt Disney Company (DIS), Time Warner Inc. (TWX), Comcast Corporation (CMCSA) Viacom Inc. (VIA), Sony Corporation (SNE), and Twenty-First Century Fox (FOX). Market share of Disney is $14.3 \%$ in entertainment-diversified industry. The Walt Disney Company functions as an enhanced beguilement organization around the world. Walt Disney is a standout amongst the most influential organizations, in a standout amongst the most effective areas of the amusement. Disney has a long fruitful history while as of now having the capacity to adjust with the progressions inside the business. Walt Disney changed excitement by being one of the best pioneers of filmmaking and making a few exemplary movies, for example, Snow White and the Seven Dwarfs, and Pinocchio. Walt Disney changed entertainment by being one of the greatest pioneers of filmmaking and creating several classic films, such as Seven Dwarfs and Snow White and Pinocchio. Disney changed the world by creating many cartoons, characters and the most famous theme parks that probably existed, Walt Disney World, and Walt Disney Land. Walt Disney also created one of the most popular cartoon character Mickey Mouse.Disney created new studios that used state of the art technology 
created a training school for animators. In the 1950's Disney began to produce TV shows, such as Mickey Mouse club. The development of Disney theme parks changed the perception that people had about family entertainment. Much of the new technology that was used at the parks was cutting edge and led to wide spread use of technology for family entertainment."Imagineering" was the term given to the development for new ideas and patents, such as ride systems, special effects, technology, etc. Disney's greatest strength was that he created truly impressions. The budgetary downturn keeps on taking an expanding assessment on the diversion business bringing about a declining Gross Domestic Product (GDP) that has consequently lessened the measure of optional shopper using, and organization publicizing aggravating the variables in this element industry. The longing for expanded quality has brought about the buyer to turn to computerized media and the business to concentrate on the advanced media worth chain.

\section{Financial ratio analysis:}

Financial ratio analyses for Walt Disney and for the entertainment- diversified industry are provided below.

Comparing with Industry found that The Walt Disney Company current ratio is greater than 1 , representing that their assets can shield their liabilities. It showing increasing trend in year to year analysis. Simultaneously this ratio for Walt Disney Company is lower as compared to the Industry. Meanwhile the quick ratio is higher for the Walt Disney Company that the company puts low amount of inventory as compared to industry. The Current and Quick ratios of the past years show similar trend and are increasing for the past three years. The Disney Company's total debt to equity is decreasing for the past few years as the company is focusing on major part of owner's equity for its operations and for the acquisitions and takeovers. The Walt Disney Company has higher total debt to equity as compared to the industry. Disney's inventory turnover tells the operational efficiency in the sales and the stock and it is higher than the industry average as inventory is the least liquid form of an asset, Disney is strong in sales \& effective buying and doing more for enhancing Disney's ability to efficiently use its assets to produce more revenue as its inventory turnover is high in many years. The trend of Earning per Share is also increasing, this might show that the efficiency in the earnings and the company is highly profitable and its net profit margin is also increasing year by year. This shows the good health of the company as compared to the industry.

Walt Disney's Financial Ratio Analysis 1999 to 2013

\begin{tabular}{|l|l|l|l|l|l|l|l|}
\hline Year & $\begin{array}{l}\text { Current } \\
\text { Ratio }\end{array}$ & $\begin{array}{l}\text { Quick } \\
\text { Asset } \\
\text { Ratio }\end{array}$ & $\begin{array}{l}\text { Debt } \\
\text { Equity } \\
\text { Ratio }\end{array}$ & $\begin{array}{l}\text { Inventory } \\
\text { Turnover }\end{array}$ & $\begin{array}{l}\text { Earnings } \\
\text { Per Share }\end{array}$ & $\begin{array}{l}\text { Net } \\
\text { Profit } \\
\text { Margin }\end{array}$ & $\begin{array}{l}\text { Interest } \\
\text { Coverage } \\
\text { Ratio }\end{array}$ \\
\hline $\mathbf{2 0 1 3}$ & 1.20 & 1.07 & 0.68 & 29.78 & 3.42 & 14.73 & 37.00 \\
\hline $\mathbf{2 0 1 2}$ & 1.06 & 0.94 & 0.78 & 26.99 & 3.17 & 14.60 & 22.39 \\
\hline
\end{tabular}




\begin{tabular}{|l|l|l|l|l|l|l|l|}
\hline $\mathbf{2 0 1 1}$ & 1.13 & 1.006 & 0.82 & 26.92 & 2.56 & 12.85 & 20.74 \\
\hline $\mathbf{2 0 1 0}$ & 1.11 & 0.98 & 0.75 & 28.06 & 2.07 & 11.33 & 14.12 \\
\hline $\mathbf{2 0 0 9}$ & 1.33 & 1.18 & 0.87 & 30.19 & 1.76 & 09.98 & 9.90 \\
\hline $\mathbf{2 0 0 8}$ & 1.00 & 0.90 & 0.93 & 42.88 & 2.28 & 11.69 & 12.01 \\
\hline $\mathbf{2 0 0 7}$ & 0.99 & 0.93 & 0.98 & 53.20 & 2.34 & 13.19 & 11.20 \\
\hline $\mathbf{2 0 0 6}$ & 0.93 & 0.86 & 0.88 & 51.95 & 1.68 & 09.84 & 7.40 \\
\hline $\mathbf{2 0 0 5}$ & 0.96 & 0.89 & 1.02 & 45.60 & 1.25 & 07.92 & 4.86 \\
\hline $\mathbf{2 0 0 4}$ & 0.84 & 0.77 & 1.06 & 41.61 & 1.14 & 07.63 & 4.45 \\
\hline $\mathbf{2 0 0 3}$ & 0.95 & 0.87 & 1.10 & 38.66 & 0.65 & 04.68 & 1.42 \\
\hline $\mathbf{2 0 0 2}$ & 1.003 & 0.91 & 1.13 & 37.03 & 0.61 & 04.88 & 3.33 \\
\hline $\mathbf{2 0 0 1}$ & 1.13 & 1.02 & 0.92 & 36.80 & -0.02 & -0.63 & 3.35 \\
\hline $\mathbf{2 0 0 0}$ & 1.19 & 1.10 & 0.86 & 33.92 & 0.58 & 03.62 & 3.71 \\
\hline $\mathbf{1 9 9 9}$ & 1.32 & 1.22 & 1.08 & 29.40 & 0.63 & 05.55 & 2.78 \\
\hline
\end{tabular}

(Source: Walt Disney, Co, 2013-1999)

Disney's profit margin is increasing yearly indicating that they have a higher level of earnings. Industry average is light marginally higher than Disney's. Disney's Price profit proportion is higher than the business; this suggests that shareholders need higher income development later on. The cost to book proportion contrasts a securities exchange's quality with its book esteem. Disney is near the business' normal so this appears to be esteemed accurately, however one must be mindful that this could differ by industry.Asset turnover of Disney showing that it is performing well and it is more than the industry average. It means that Disney performing additional to enhance its capability and efficiently using its assets to produce more revenue. 
2013 Financial Ratio Analysis

\begin{tabular}{|l|l|l|}
\hline RATIOS & WALT DISNEY & INDUSTRY \\
\hline Current ratio & 1.20 & 1.25 \\
\hline Quick ratio & 1.07 & 0.97 \\
\hline Debt/ Equity Ratio & 0.68 & 0.49 \\
\hline Inventory Turnover Ratio & 29.78 & 12.62 \\
\hline Net Profit Margin & 14.73 & 14.75 \\
\hline Asset Turnover & 0.55 & 0.51 \\
\hline Return on Equity & 13.78 & 16.31 \\
\hline Return on Asset & 8.17 & 7.54 \\
\hline Interest Coverage Ratio & 37.00 & 14.05 \\
\hline
\end{tabular}

(Source: Walt Disney, Co, 2013)

The return on assets (ROA) showing that Disney's management efficiency is increasing yearly. This is higher than the industry average. The ROA showing that management is more efficiently using its assets to generate more earnings. The return on equity (ROE) is increasing every year \& highest in 2012. It is a lilted bit lowers than then the industry average. It showing that profits are using to make the money the actual shareholders have invested. Interest coverage ratio is better than the industry average, as the ability to pay interest is better due to the more revenue. It is substantively higher ratio representing it can meet its debt commitments many times over. It is higher in 2013 than all previous years.

There are various explanations to reflect when defining whether a stock is a good investment, not just whether the unrestricted cash flows are optimistic. Disney endures to construct shareholder's wealth through making bright acquisitions and sustainable competitive advantage in the diversified industry. The Walt Disney Company is a well-established conglomerate which stays to be a leader in entertainment industry. So asentire we can say that Disney Company's performing well in 2013 as compared to all previous years and overall it is efficiently succeeded in the industry and most of the performance measuring ratios are better than industry which can be easily understand by the following graphic representation of the Walt Disney \& Industry average ratios. 


\section{Dupont System Of Disney's Financial Analysis}

The DuPont analysis of Walt Disney and its industry is shown in the Table but before discussing the DuPont Analysis there is a trend analysis of ROE and ROI in the Walt Disney Company.

\begin{tabular}{|l|l|l|l|l|l|l|l|l|l|l|l|l|l|l|l|}
\hline & 2013 & 2012 & 2011 & 2010 & 2009 & 2008 & 2007 & 2006 & 2005 & 2004 & 2003 & 2002 & 2001 & 2000 & 1999 \\
\hline ROI & 8.16 & 8.24 & 7.29 & 6.23 & 5.71 & 7.08 & 7.69 & 5.62 & 4.76 & 4.35 & 2.53 & 2.46 & -0.4 & 2.04 & 2.97 \\
\hline ROE & 13.8 & 14.7 & 13.3 & 10.9 & 10.7 & 13.7 & 15.2 & 10.6 & 9.66 & 8.99 & 5.32 & 5.27 & -0.7 & 3.81 & 6.19 \\
\hline
\end{tabular}

(Source: Walt Disney, Co, 2013-1999)

On average there is an increasing trend and same structure of the line graph in ROI and ROE. In year 2001, both were below the positive line showing that the return was negative (ROE= $-0.69 \&$ ROI $=-0.36$ ) but afterwards 2007 it was the highest and now it is moving on average. This is a good indicator of a Disney's performance.

\section{Line Graph of ROE \& ROI}

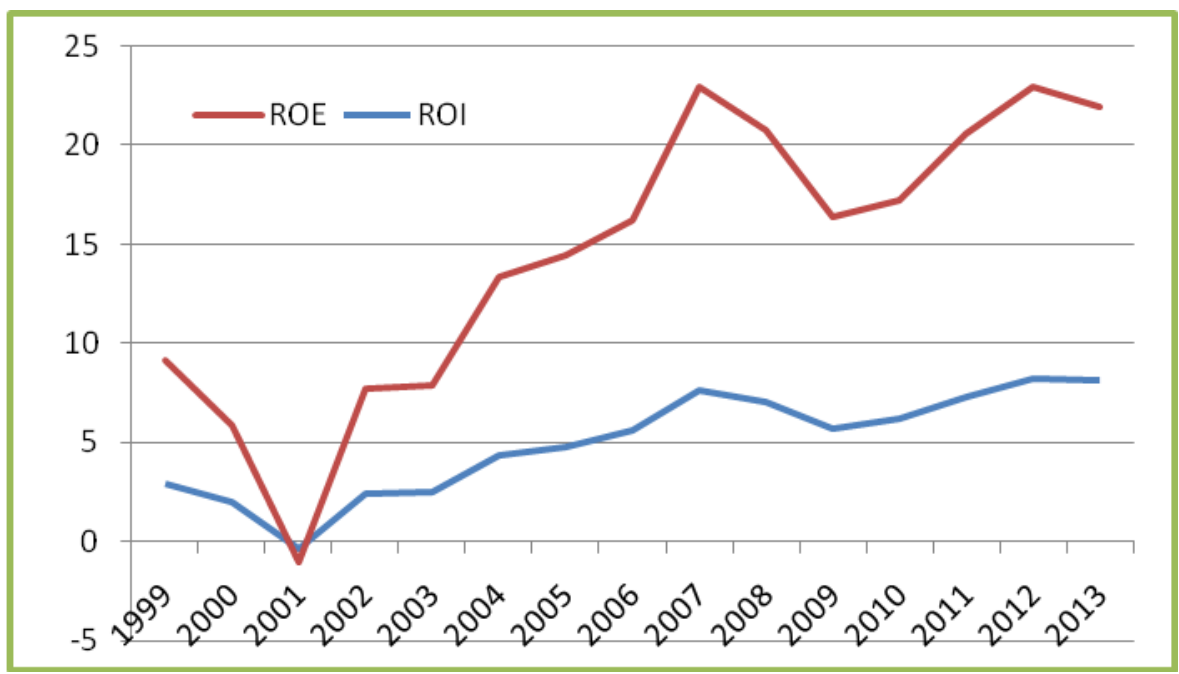


DuPont Analysis of Walt Disney \& Entertainment Industry

\begin{tabular}{|lll|}
\hline & WALT DISNEY & INDUSTRY \\
ROE (Return on Equity) & $\mathbf{1 3 . 7 8 \%}$ & $\mathbf{1 6 . 6 4 \%}$ \\
$=$ & $=$ & $=$ \\
NPM (Net Profit Margin) & $14.73 \%$ & $15 \%$ \\
X & $\mathrm{X}$ & $\mathrm{X}$ \\
TAT (Total Asset Turnover) & 0.55 & 0.51 \\
X & $\mathrm{X}$ & $\mathrm{X}$ \\
EQ (Equity Multiplier) & 1.68 & 2.17 \\
ROI (Return on Investment) & $\mathbf{8 . 1 6 \%}$ & $\mathbf{7 . 6 5 \%}$ \\
$=$ & $=$ & $=$ \\
NPM (Net Profit Margin) & $14.73 \%$ & $15 \%$ \\
X & $\mathrm{X}$ & $\mathrm{X}$ \\
TAT (Total Asset Turnover) & 0.55 & 0.51 \\
\hline
\end{tabular}

(Source: Walt Disney, Co, 2013, p.75

$\mathrm{ROE}=\mathrm{NPM} * \mathrm{TAT} * \mathrm{~A} / \mathrm{E}=\mathbf{R O A} * \mathrm{~A} / \mathrm{E}$

DuPont Analysis of Walt Disney and the industry averages shows the same pattern as that of ratio analysis. Walt Disney has less net profit margin but more asset turnover as compared to the industry showing that operations are efficient but due to more net profit margin the ROI is comparatively higher. ROI is higher means the net gain that is extracted over an investment is higher as compared to the industry. ROI is usually represented as a percentage and is usually used for the financial decisions of the company. Whereas the leverage ratio is low as compared to the industry showing that the company has to pay low interests because the equity has a low portion of debt and the net ROE is also lower of Walt Disney showing that the company is less efficient is utilizing its equity to get return. This difference might be short term low earnings of the Walt Disney but in long run the company is operating efficiently in all its five segments.

\section{Short Term Liquidity Management}

The entertainment industry average current ratio of 1.25 and quick ratio is 0.97 , but Walt Disney current and quick ratios are $1.20 \& 1.07$ respectively that associates positively to the industry. This comparison representing that Walt Disney is also in a solid short term liquidity position. 


\section{Macrothink}

International Journal of Accounting and Financial Reporting

ISSN 2162-3082

In Walt Disney's case there have been very concrete improvements in its liquidity position since 2010 to 2013.These improvements come from reduction in account payable and current position of long term borrowing. But a considerable portion of improvements is credited to large increase in cash \& cash equivalents. The firm's cash balance is sufficient to meet the expenses of manufacturing and selling products. 


\begin{tabular}{|c|c|c|c|}
\hline 2013 & 20 & 2010 & 2009 \\
\hline \multicolumn{2}{|c|}{ Cash and cash equivalents } & \multirow[t]{2}{*}{3,931} & \multirow[t]{2}{*}{3,387} \\
\hline 3,185 & 3,417 & & \\
\hline \multicolumn{2}{|c|}{ Short term investments } & \multirow[t]{2}{*}{2,849} & \multirow[t]{2}{*}{2,723} \\
\hline $2,435 \quad 2,513$ & 2,554 & & \\
\hline \multicolumn{2}{|c|}{$\begin{array}{lll}\text { Account } & \text { receivables, } & \text { net } \\
6,182 & 5,784 & 4,854\end{array}$} & 6,967 & $\mathbf{6 , 5 4 0}$ \\
\hline \multicolumn{3}{|l|}{ Inventories, net } & \multirow[t]{2}{*}{1,487} \\
\hline 1,595 & 1,442 & 1,271 & \\
\hline \multicolumn{2}{|l|}{ Other current assets } & \multirow[t]{2}{*}{605} & \multirow[t]{2}{*}{804} \\
\hline 581 & 576 & & \\
\hline \multicolumn{2}{|l|}{ Total current assets } & \multirow[t]{2}{*}{14,109} & \multirow[t]{2}{*}{13,709} \\
\hline $13,757 \quad 12,225$ & 11,889 & & \\
\hline \multicolumn{2}{|c|}{$\begin{array}{llr}\text { Current } & \text { position of } & \text { debt } \\
6,795 & 6,104 & 5,444\end{array}$} & 4,561 & 7,179 \\
\hline \multicolumn{3}{|l|}{ Accounts payable } & \multirow[t]{2}{*}{6,803} \\
\hline 6,393 & 6,109 & 5,616 & \\
\hline \multirow{2}{*}{\multicolumn{2}{|c|}{$\begin{array}{l}\text { Total current liabilities } \\
\begin{array}{lll}32,671 & 29,864 & 29,383\end{array}\end{array}$}} & \multirow[t]{2}{*}{33,091} & \multirow[t]{2}{*}{32,940} \\
\hline & & & \\
\hline \multicolumn{2}{|l|}{ Current ratio } & & \multirow[t]{2}{*}{1.20} \\
\hline 1.14 & 1.11 & 1.33 & \\
\hline \multicolumn{2}{|l|}{ Quick ration } & & \multirow[t]{2}{*}{1.08} \\
\hline 0.95 & 0.98 & 1.19 & \\
\hline \multicolumn{2}{|l|}{ Net working capital } & \multirow[t]{2}{*}{2,405} & \multirow[t]{2}{*}{896} \\
\hline 1,669 & 2,955 & & \\
\hline
\end{tabular}

(Source: Walt Disney, Co, 2013-2009) 


\section{$\Lambda$ Macrothink}

\section{Horizontal Analysis}

In Horizontal Analysis of Walt Disney, both assets \& the liabilities costs went up, however stockholders equity went down. This analysis representing that overall the company has more assets \& expenses, so the likelihoods of profit are not so high. The short term liquidity shows that in current assets there is not a significant percent change in the current asset but from 2010 to 2011 it as almost $12.5 \%$, meanwhile in current liabilities the change was very wide, it was $23 \%$ from 2009 to 2010 while declining in the next years i.e. $9.8 \%, 5.99 \%$ and finally $-8.65 \%$ in 2013 . This shows that the liquidity position is improving year by year. In debt percent change was declining while in total change is more in the more current years. Since the stockholders value went down this implies that there has been either less reliance on the stockholders to help or that stockholders have sold off their stock and no more help Disney. Since the economy has been in the decay it is most likely more probable that stockholders have sold their stock and the Disney Corporation has must be all the more financially autonomous from their stockholders. (journalofaccountancy.com)

\section{Common Size Analysis (Vertical Analysis)}

A vertical analysis sheet maps out where their money is coming from and what it is going into. As per analysis, most of the benefits are made up of property plant and gear. There is a more stupendous rate of current possessions long haul ventures and different holdings in latest than previous. However they decrease property plan \& gear, goodwill, and elusive stakes. As for the liabilities and Stockholder's value, there was a drop in long haul obligation however their different liabilities went up. The stockholders value likewise expanded, as there must have been a requirement for more money stream and accessible subsidizes in the year 2008 than previous years.

\section{Short term Liquidity Position:}

After having computed liquidity ratios measure the Disney's ability to meet its short-term obligations\& also to determine marketability. Short term liquidity position of Walt Disney is quite well and is going overall better, it was declining till 2000 and from 2001 to 2013 it is moving towards betterment that there are strong cash flows. One possible reason would that in 2001 Walt Disney acquired Fox Family Network which gave it a boost and its long term financial position also got well. Walt Disney is operating very well in the industry because industry has no such big competitor for Walt Disney and the small competitors could not stay before this company. 


\section{Macrothink}

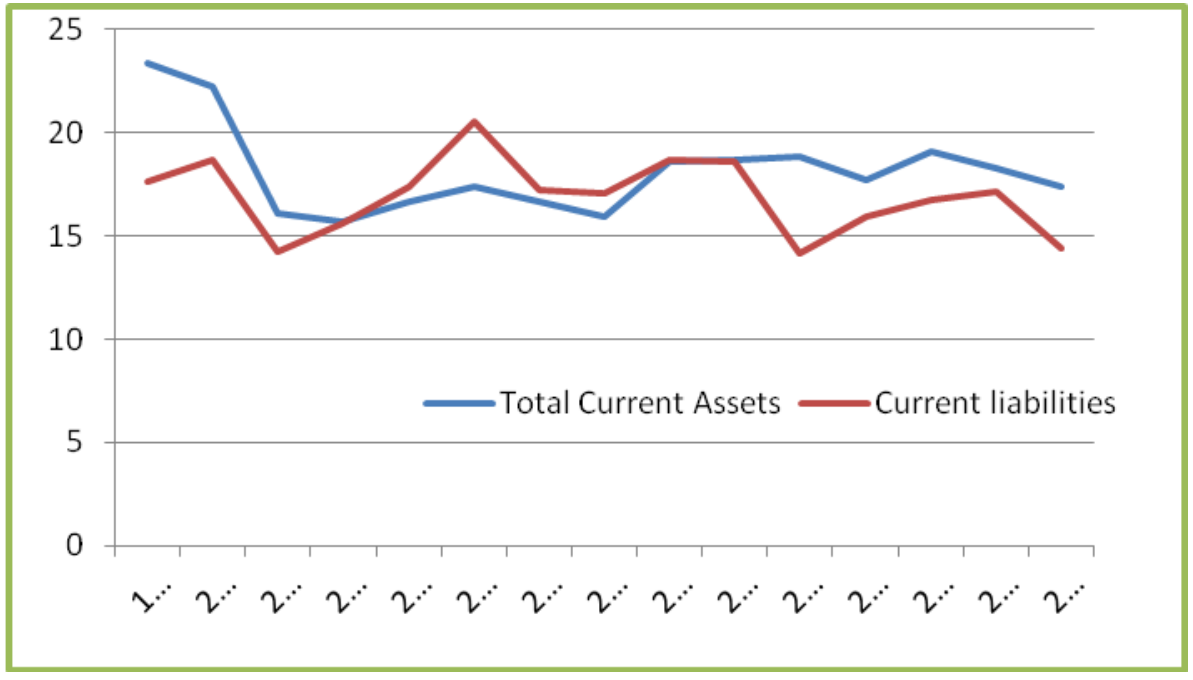

(These figures are relative to sales)

\section{Disney Capital Structure and Debt Management:}

The solvency of a Disney is its ability to persist for a lengthy period of time. From data, it is evident that there has been a major change in Walt Disney's capital structure over the last several years.Disney's long term debt increased by more than $44 \%$ in 2008 to 2009 . From the data, it does not appear that Disney has a strict or a tight debt-equity ratio that they maintain to balance the benefits of debt (primarily, the tax savings due to interest) with the cost of debt (primarily, financial distress costs).

The Debt was relatively higher in this company till 2011 and the company was near to 50-50 Debt-Capital combination, and it was very undesirable as company was under high debt but for the time being the company is focusing on the getting less debt from other sources. The data does not show the exact strategy of controlling the check and balance upon debt equity ratio. But it seems that Walt Disney is following a standard ratio of 60:40 from the previous year. But sometimes debt ratio increases from 60:30 to 70:30.

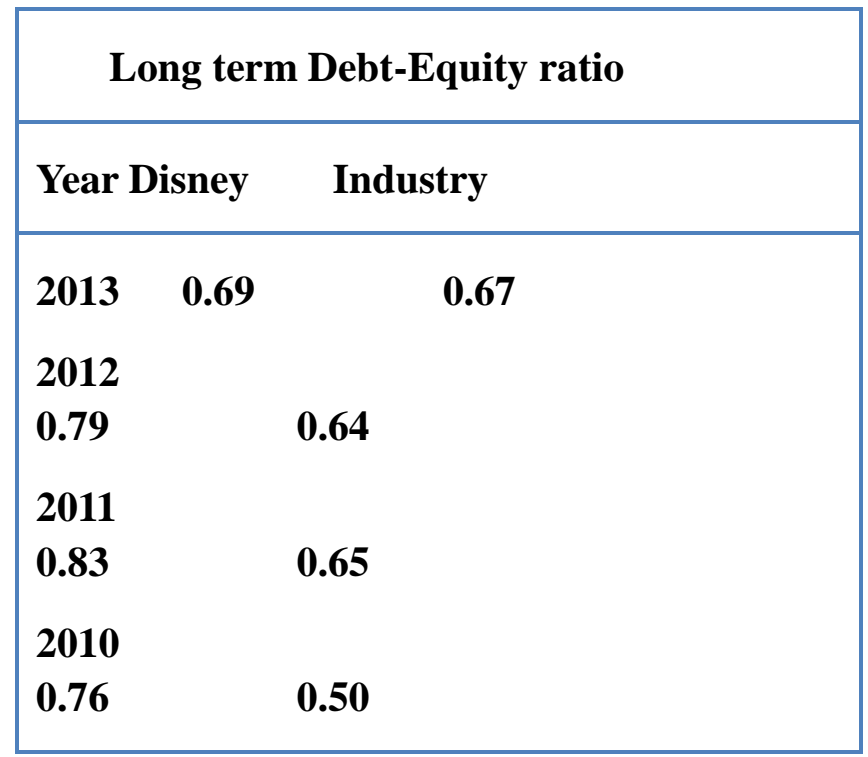


(Source: Walt Disney,Co, 2013-2009)

Debt Structure of the company shows a combination of short term and long term liabilities, the long term liabilities show a major part of the structure means the company investment is more risky. WaltDisney's debt equity ratio is 0.69 , which is higher than the industry average of 0.67. It may have two aspects. On the one side it shows that company is using its debt efficiently in its operations. On the other side it may also wasting its funds. But the capital structure and the revenue of Walt Disney show that the company is using its funds efficiently. But as compare its debt equity ratio with the industry ratio Walt Disney is trying to come parallel its industry ratio. Company has acquired so much firms that now it is focusing on self-financed acquisitions and operations. As Warren Befflet said that the durable competitive advantage comes with little or no long term debt. Walt Disney is so profitable that its acquisitions should be self-financed.

\section{Efficiency \& Profitability:}

Disney's profitability is very strong\& high to the situations of the market and in fact they are concrete and on the margin of growing in some ranges due to their pioneering products and planning. The operating as well as direct expenses show a declining trend relative to sales, means the company is working efficiently and utilizing its assets in a better manner that is covering its fixed as well as variable cost. Basically Disney keeps their costs in control. This might be due to the reason that after 1999 company has acquired Fox family Network, repurchased DIC Entertainment, acquired Lucas Films and launched Disney XD. All these and some other major changes allowed Disney to work more efficiently. The overall profits show an upward trend that means this company is highly profitable, which reflecting that Disney doing more efforts to enhance revenues.

\section{Management Operations:}

Managing the operations of five theme park and resort destinations around the world, as well as a variety of other Disney vacation and leisure enterprises is quite an undertaking, but the management of the Walt Disney possessed the skilled and talented employees who are responsible for the management operations. They have an overview of the inventory turnover which express about the liquidity position of the company. The overall operations of the company are in better position as the costs are decreasing and the profits are increasing with decreasing liabilities show that the company is using all its resources to work more competitively and efficiently in the entertainment industry.

\section{Discussion}

A recent study of Robbins School of Business 2012 states that Walt Disney never afraid to dream big and did things that were supposed to be impossible (Mink, M. 2007)and it 


\section{MInstitute Macrothink $_{\text {Int }}$}

International Journal of Accounting and Financial Reporting ISSN 2162-3082 2014, Vol. 4, No. 1

achieved its big dreams by establishing such a giant business empire that it lacks competitors. (Himmelberg, M. 2005) Walt Disney had a successful history from start, and it continued its growth through acquisitions and defeated the competitors. In 1993, Disney acquired Miramax Film Corporation from Harvey and Bob Weinstein for about $\$ 70$ million as mentioned by Orwall, B. in 2004. Miramax operated as a separate unit of Disney and by 2005 it was valued over $\$ 2$ billion. The relationship of Disney became weaker with Weinstein Brothers therefore Miramax was sold to Tutor Saliba Corp in 2010. (Nakashima, R. 2010) The other major purchase was on July 31, 1995 with the purchase of Capital Cities/ABC for \$19 billion. (Business Wire, 1995) This acquisition became the reason for Disney to enter in the television and the cable networks of ABC and ESPN. Disney acquired Pixar in May 2006 for $\$ 7.4$ billion. (Avalos, G. 2006) This deal was beneficial for Pixar as well as for Disney, as Pixar had computer animation power and Disney had the distribution strength. Due to Pixar Steve Jobs, Founder of Apple, Joined BOD of Walt Disney. (Marr, M. and Wingfield, N. 2006) In 2009, Disney acquired Marvel Entertainment for approximately $\$ 4$ billion. This acquisition was helpful for Disney in accessing various Comic Characters like Spider Man, X-Man, etc., and recently in 2012 Disney acquired Lucas films.

The purpose of the above discussion was to have a view on the achievements of Disney that were helpful for the company to grow and stand in its current position that is really very strong, in terms of good will and financial stability. Walt Disney is sustaining its current position as a leader in the entertainment diversified industry due to the continuous innovation and by acquiring its related businesses, and continuously growing its segments.

\section{Future Prospects}

The Walt Disney Company has formed three strategic priorities i.e. creativity in innovation, expand globally and technology application. In the first strategic priority, creative innovation, $\mathrm{ABC}$ has proved by broadcasting five out of top $10 \mathrm{TV}$ series. As far as second priority is concerned, expand globally, then success Hong Kong Disneyland and Mickey Mouse Magazine in China is an indication of world recognition of the company. The Company also introduced Toon Disney and Disney channel in India, and in this way it is growing by investing in new markets. The third focus of the company is technology application; company knows the importance of the changing technology and as a result the alteration in distribution channel. Disney has an association with Apple Inc., to provide ABC and Disney Channel content to the iPod users. The company is highly in the favor of thinking out of the box. Disney is moving towards a future where advanced technology and globalization is its core achievement. The company is increasing its global presence and achieving its goals regarding this.

\section{Conclusion}

Walt Disney is a company that never afraid of dreaming big, it is currently participating in the multiple business ventures both in media industry and technology, and also operating in some other business projects. Growth of Disney might be a result of the demand of consumer and the success story of the company started from a small cartoon to a multi-billion pound international business. Disney is now strengthening its presence in many markets e.g. 


\section{Macrothink}

International Journal of Accounting and Financial Reporting ISSN 2162-3082 2014, Vol. 4, No. 1

children films and TV shows, theme parks, digital media and live productions. US children TV ratings show that Disney is crossing its heights day by day, it is evident that 7 of the Disney's channels are rated in the top 20 most children TV programs in US. Although the universal entertainment symbol the Walt Disney is normally taken as a stable and growing firm but the company is less stable with respect to cash flows, profit margins and the return on investments. This kind of discrepancies might be a result of one or more aspects of business, but the company is still creating opportunities for the people who are willing to invest.

\section{Annexure I}

Trend Analysis of Walt Disney's Financial Ratios (1999-2013)

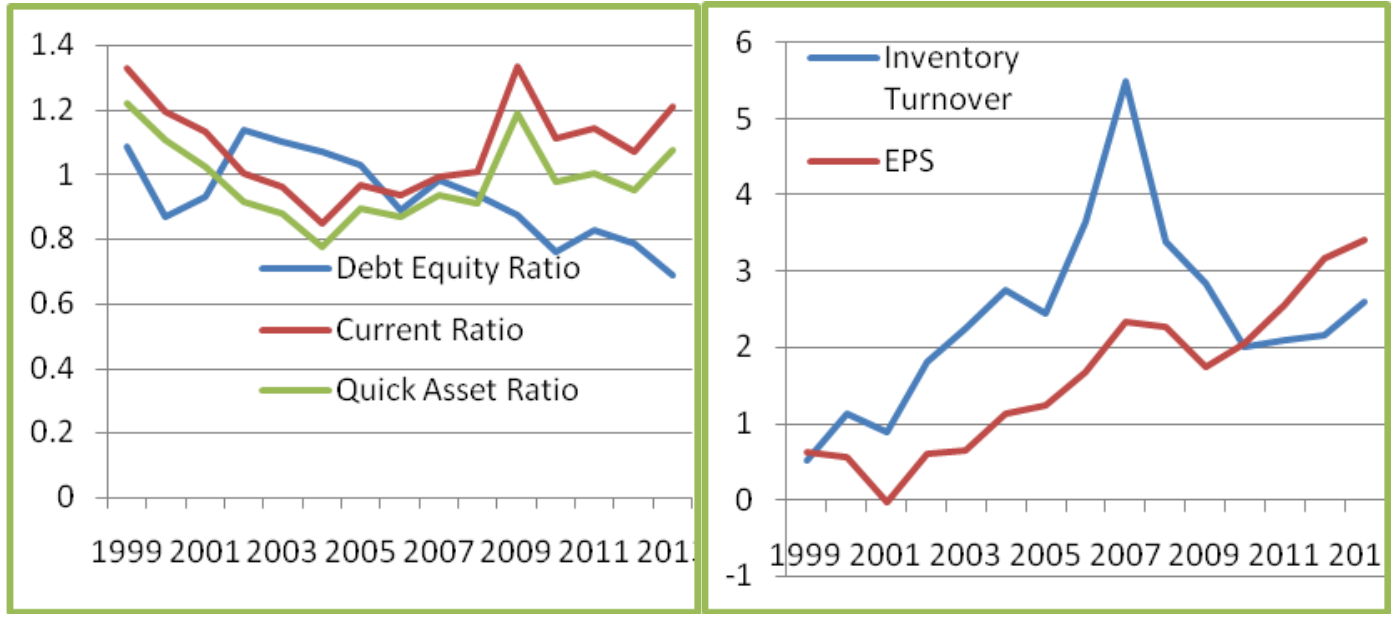

Graph 1 (a) Graph 1 (b)

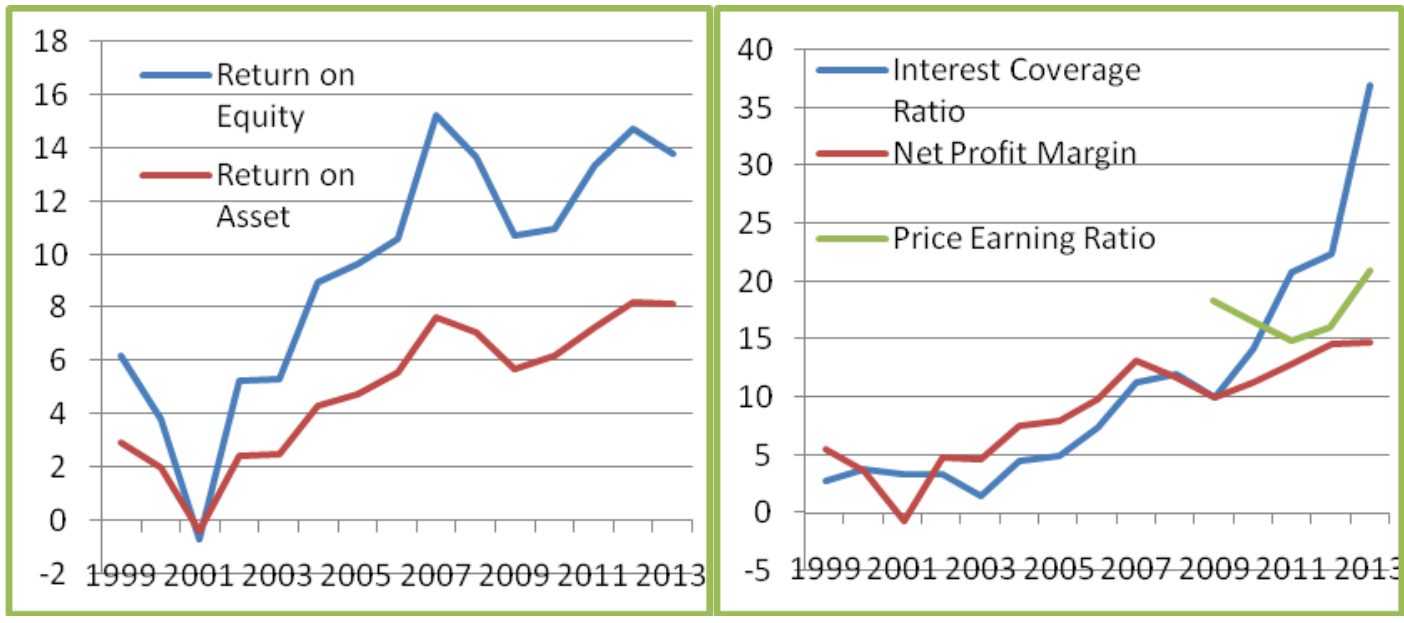

Graph 1 (c) Graph $1(d)$ 


\section{Annexure II}

Graphic Representation of Walt Disney's financial ratios with Industry Averages

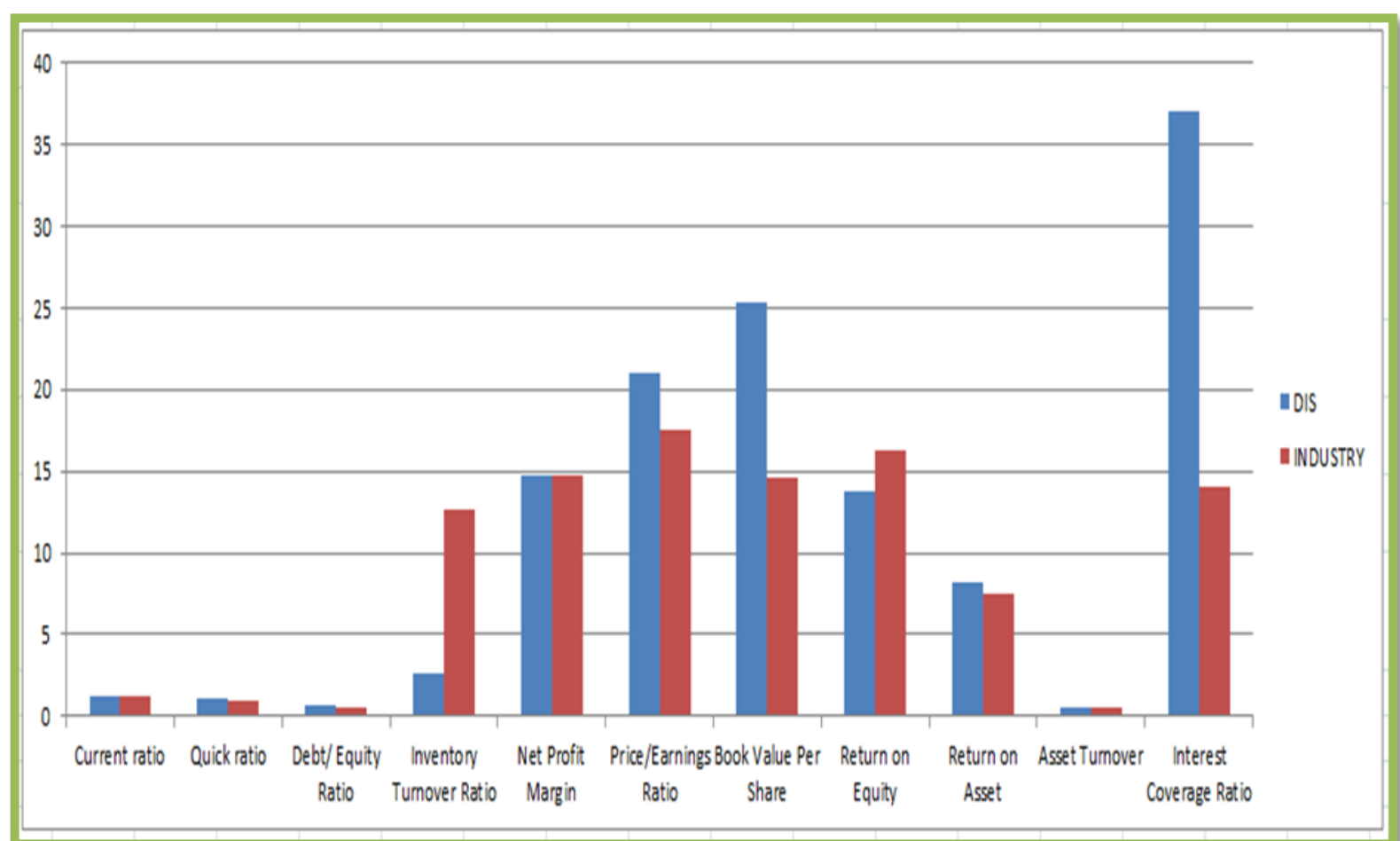




\listitute

\section{Annexure III}

\section{Horizontal Analysis}

Walt Disney Company

Consolidated Balance Sheets

(In Percentage)

\begin{tabular}{|c|c|c|c|c|c|c|c|c|c|}
\hline $\begin{array}{l}\text { Items } \\
\text { Years }\end{array}$ & Cash & $\begin{array}{l}\text { Account } \\
\text { Receivables }\end{array}$ & Inventory & $\begin{array}{l}\text { Deferred } \\
\text { income } \\
\text { taxes }\end{array}$ & $\begin{array}{l}\text { Total } \\
\text { Current } \\
\text { Assets }\end{array}$ & Invest-ment & $\begin{array}{l}\text { Intangible } \\
\text { assets }\end{array}$ & Goodwill & $\begin{array}{l}\text { Total } \\
\text { Assets }\end{array}$ \\
\hline 2013 & 16 & 6.529 & -3.2530 & -36.601 & 2.9177 & 4.63 & 46.9591 & 8.82 & 8.47 \\
\hline 2012 & 6 & 5.791 & -3.6363 & -48.554 & -0.3489 & 11.82 & -2.06990 & 3.4 & 3.85 \\
\hline 2011 & 17 & 6.881 & 10.610 & 46.070 & 12.531 & -3.10 & 0.7872 & 0.19 & 4.22 \\
\hline 2010 & -20 & 19.15 & 13.453 & -10.701 & 2.8261 & -1.61 & 126.123 & 11.15 & 9.65 \\
\hline 2009 & 14 & 9.659 & 13.078 & 11.328 & 1.9115 & 63.40 & -7.45469 & -2.1 & 0.99 \\
\hline
\end{tabular}

\begin{tabular}{|c|c|c|c|c|c|c|c|c|c|}
\hline $\begin{array}{l}\text { Account } \\
\text { Payables }\end{array}$ & $\begin{array}{l}\text { Current } \\
\text { Position of } \\
\text { Borrowing }\end{array}$ & $\begin{array}{l}\text { Current } \\
\text { Liabilities }\end{array}$ & $\begin{array}{l}\text { Deferred } \\
\text { Tax } \\
\text { liabilities }\end{array}$ & $\begin{array}{l}\text { Long } \\
\text { Term } \\
\text { Debt }\end{array}$ & $\begin{array}{l}\text { Common } \\
\text { Stock }\end{array}$ & $\begin{array}{l}\text { Retained } \\
\text { Earnings }\end{array}$ & Losses & $\begin{array}{l}\text { Treasury } \\
\text { Stock }\end{array}$ & $\begin{array}{l}\text { Total } \\
\text { Liabilities } \\
\text { and } \\
\text { Equity }\end{array}$ \\
\hline 6.41 & -58.16 & -8.65 & 79.92 & -36.4 & 5.385 & 11.15 & -63.655 & 9.19 & 8.468 \\
\hline 0.49 & 18.29 & 5.99 & -21.45 & 5.651 & 4.736 & 11.96 & 24.182 & 10.5 & 3.846 \\
\hline 4.14 & 30 & 9.89 & 8.97 & 11.32 & 5.428 & 11.79 & 39.819 & 21.1 & 4.216 \\
\hline 8.78 & 94.85 & 23.12 & 44.584 & 12.12 & 6.280 & 10.61 & 14.416 & 4.27 & 9.647 \\
\hline-6.09 & -65.82 & -22.92 & -22.59 & 44.05 & 1.853 & 9.221 & 1929. & 0.6 & 0.992 \\
\hline
\end{tabular}




\section{Annexure IV}

Vertical Analysis

Walt Disney Corporation

Common Size-Balance Sheets

(In Percentage)

$\begin{array}{llllllllllll}\begin{array}{l}\text { Items } \\ \text { Years }\end{array} & \text { Cash } & \text { A/R } & \text { Inventories } & \begin{array}{l}\text { Deferred } \\ \text { income } \\ \text { taxes }\end{array} & \begin{array}{l}\text { Total } \\ \text { Current } \\ \text { Assets }\end{array} & \begin{array}{l}\text { Film and } \\ \text { Television } \\ \text { Cost }\end{array} & \text { Investment } & \begin{array}{l}\text { Intangible } \\ \text { assets }\end{array} & \text { Good-will } & \begin{array}{l}\text { Total } \\ \text { assets }\end{array} \\ \mathbf{2 0 1 3} & 4.838 & 8.57 & 1.830 & 0.59 & 17.366 & 5.8874 & 3.50 & 9.0717741 & 33.63 & 100 \\ \mathbf{2 0 1 2} & 4.522 & 8.73 & 2.0521 & 1.02 & 18.30 & 6.0629 & 3.63 & 6.69577292 & 33.52 & 100 \\ \mathbf{2 0 1 1} & 4.41 & 8.57 & 2.211 & 2.06 & 19.074 & 6.0409 & 3.37 & 7.10027175 & 33.47 & 100 \\ \mathbf{2 0 1 0} & 3.93 & 8.35 & 2.083 & 1.47 & 17.664 & 6.8968 & 3.63 & 7.34184897 & 34.8 & 100 \\ \mathbf{2 0 0 9} & 5.41 & 7.69 & 2.013 & 1.80 & 18.836 & 8.1198 & 4.04 & 3.56005514 & 34.35 & 100\end{array}$

\begin{tabular}{llllllllll} 
A/P & $\begin{array}{l}\text { Current } \\
\text { Position of } \\
\text { Borrowing }\end{array}$ & $\begin{array}{l}\text { Current } \\
\text { Liabilities }\end{array}$ & Borrowings & $\begin{array}{l}\text { Long-term } \\
\text { debt }\end{array}$ & $\begin{array}{l}\text { Common } \\
\text { Stock }\end{array}$ & $\begin{array}{l}\text { Retained } \\
\text { Earnings }\end{array}$ & $\begin{array}{l}\text { Total } \\
\text { Shareholders' } \\
\text { Equity }\end{array}$ & $\begin{array}{l}\text { Total } \\
\text { Liabilities } \\
\text { and } \\
\text { Equity }\end{array}$ \\
8.37 & 1.86 & 14.40 & 15.72 & 5.61 & 41.16 & 58.78 & 59.26 & 100 \\
8.53 & 4.82 & 17.10 & 14.28 & 9.58 & 42.36 & 57.36 & 56.02 & 100 \\
8.82 & 4.23 & 16.76 & 15.14 & 9.42 & 42.00 & 53.20 & 54.70 & 100 \\
8.82 & 3.39 & 15.89 & 14.63 & 8.82 & 41.52 & 49.6 & 56.87 & 100 \\
8.89 & 1.911 & 14.16 & 18.21 & 8.63 & 42.83 & 49.16 & 53.44 & 100 \\
\hline
\end{tabular}




\section{References:}

- Walt Disney, Co. (1999). Annual report. Retrieved from http://www.thewaltdisneycompany.com

- Walt Disney, Co. (2000). Annual report. Retrieved from http://www.thewaltdisneycompany.com

- Walt Disney, Co. (2001). Annual report. Retrieved from http://www.thewaltdisneycompany.com

- Walt Disney, Co. (2002). Annual report. Retrieved from http://www.thewaltdisneycompany.com

- Walt Disney, Co. (2003). Annual report. Retrieved from http://www.thewaltdisneycompany.com

- Walt Disney, Co. (2004). Annual report. Retrieved from http://www.thewaltdisneycompany.com

- Walt Disney, Co. (2005). Annual report. Retrieved from http://www.thewaltdisneycompany.com

- Walt Disney, Co. (2006). Annual report. Retrieved from http://www.thewaltdisneycompany.com

- Walt Disney, Co. (2007). Annual report. Retrieved from http://www.thewaltdisneycompany.com

- Walt Disney, Co. (2008). Annual report. Retrieved from http://www.thewaltdisneycompany.com

- Walt Disney, Co. (2009). Annual report. Retrieved from http://www.thewaltdisneycompany.com

- Walt Disney, Co. (2010). Annual report. Retrieved from http://www.thewaltdisneycompany.com

- Walt Disney, Co. (2011). Annual report. Retrieved from http://www.thewaltdisneycompany.com

- Walt Disney, Co. (2012). Annual report. Retrieved from http://www.thewaltdisneycompany.com

- Walt Disney, Co. (2013). Annual report. Retrieved from http://www.thewaltdisneycompany.com

- Brett Chatz, (2013).Walt Disney Delivers In Time For The Holidays, retrieved fromhttp://seekingalpha.com/article/1880211-walt-disney-delivers-in-time-for-the-holid ays 


\section{Macrothink}

International Journal of Accounting and Financial Reporting ISSN 2162-3082

- Dividend \& stock prices (2013). retrieved from https://ca.finance.yahoo.com/q/hp?s=DIS\&a=00\&b=31\&c=2000\&d=11\&e=31\&f=2013 $\& \mathrm{~g}=\mathrm{m})$

- Andrew Beattie, (2011).Walt Disney: How Entertainment Became An Empire, retrieved fromhttp://www.investopedia.com/articles/financial-theory/11/walt-disney-entertainmen t-to-empire.asp

- The Film and Entertainment Industry: Reel in the Profits, retrieved from http://www.bidnessetc.com/20818-film-entertainment-industry-reel-profits/

- Industry ratios retrieved fromhttp://biz.yahoo.com/p/sum_conameu.html

- Industry ratios retrieved from http://investing.money.msn.com/investments/key-ratios?symbol=DIS

- Robbins School of Business, November (2012).The Walt Disney Company: A Corporate Strategy Analysis.

- Mink, M. (2007). Walt Disney designed dreams. Investor's Business Daily, July 5, 2007.

- Himmelberg, M. (2005). Setting the bar high // in the years to come, Disneyland's challenge will be to keep up its aura of innocence while it keeps pace with a wiser clientele. The Orange County Register, July 17, 2005.

- Orwall, B. (2004). Pulp Friction: After Years of Battling Miramax, Disney Might Redo the Script; Weinstein Brothers Produced Many Hits, but Departed From Their Early Mission; Heat From 'Fahrenheit 9/11'; Wall Street Journal, June 24, 2004.

- Nakashima, R. (2010). Disney completes $\$ 663$ million sale of Miramax to construction magnate Tutor. Associated Press Newswire, December 3, 2010.

- Business Wire, (1995). Disney, Capital Cities/ABC agrees to merge; $\$ 19$ billion transaction will enhance shareholder values by creating world's leading entertainment and Communications Company, Business Wire, July 31, (1995).

- Avalos, G. (2006). Disney purchases longtime partner Pixar for $\$ 7.4$ billion, bringing together blockbuster movie powers, Knight Ridder Tribune Business News, January 25, 2006.

- Marr, M. and Wingfield, N. (2006). Disney sets $\$ 7.4$ billion Pixar Deal; Jobs to take seat on board and play integral role in setting creative course. Wall Street Journal, January $25,2006$.

- Disney,

(2012).Retrieved fromhttp://thewaltdisneycompany.com/disney-news/press-releases/2012/10/disney-acqu ire-lucasfilmltd, Accessed November 25, 2012.

- Checkonomics. Industry overview. Retrieved from

http://www.checkonomics.co.in/IndustryOverview.aspx?IID=49\&CAT=36CC1728\&IName= 


\section{Al Macrothink \\ International Journal of Accounting and Financial Reporting \\ ISSN 2162-3082 2014, Vol. 4, No. 1}

Media\%20and\%20Entertainment\&CatName=Outlook

- Disney - Current Situation and Future Plans, retrieved fromhttp://disneyssinct.wordpress.com/disney-current-situation-and-future-plans/

- Vikas, M., (2013). The Future of the Walt Disney Corporation retrieved from http://beta.fool.com/vinny3001/2013/02/22/future-walt-disney-organization/24270/

- Pride, Bill, BobHughes and Jack Kapoor, Busienss. $12^{\text {th }}$ ed. N.p.: South-Western, Cenagge Learning (2012).

- Murray, I, “Competitive Advantage, Disney: Brand Magic, Blog Spot, 15 Jan, 2009.

- Paul R, (2006). Disney buys Pixar, retrieved from http://money.cnn.com/2006/01/24/news/companies/disney_pixar_deal/

- Long term investment. from http://www.gurufocus.com/term/Long-Term\%20Debt/DIS/Long-Term\%2BDebt/Walt\% 2BDisney\%2BCo 